\title{
Self-Adjustment and Social Conflict of Multicultural Students
}

\author{
Arlia Yulfi Susanti ${ }^{1}$, A Muri Yusuf ${ }^{1}$, Firman Firman ${ }^{1}$ \\ 1Universitas Negeri Padang \\ ${ }^{*}$ Corresponding author, e-mail: liasusan469@gmail.com
}

\begin{abstract}
Social conflict became one of the phenomena commonly found in schools. To avoid conflict, good adjustment is needed. Meanwhile there are still many multi-ethnic students who have difficulty adjusting themselves to cause conflicts such as fights, disputes and debates that lead to violence. The aim is to find out the picture of adjustment and social conflict experienced by students and to know the relationship between adjustment and social conflict experienced by students. The research sample consisted of 104 students with Stratified Random Sampling. The instrument used was a questionnaire about adjusting the Likert Scale model with a reliability of 0.724 and a questionnaire about social conflict at 0.727 . The results showed that there was a significant negative relationship between adjustment and social conflict experienced by students $(r=-0.582)$. If the adjustment of students is getting better, the social conflicts experienced by students will decrease and vice versa. It means that some of the multi-ethnic students experience social conflict and counseling services are needed to resolve the conflict.
\end{abstract}

Keywords: Adjustment, social conflict

\section{Introduction}

Today many students experience social conflict in schools such as fighting with classmates, mocking friends who want to develop themselves so many are embarrassed to appear in front of the class, forcibly borrowing or asking for friend's goods, causing some students to resign and quit school. Conflict can be interpreted as a dispute and conflict which can be a serious problem in every school, so expertise is needed to manage the conflict (Supriyadi \& Evianawati, 2015). While social conflict is a conflict between individuals or society that is comprehensive in life (Hasan, 2005). Another opinion says that social conflict is a social process between two parties that is antagonistic and sometimes cannot be harmonized because both have different goals, attitudes, and value structures, which are reflected in various forms of resistance behavior, both subtly, controlled, hidden, indirect, camouflaged and open in the form of acts of violence (Hanurawan, 2012).

According to data from the Indonesian Child Protection Commission (KPAI), during January to October 2013 conflicts such as brawl increased by around 44 percent compared to the previous year, totaling 229 cases of violence between junior and senior high school 
students, where 19 students died (Anwar, 2015). Furthermore, from the results of Oktaviyana's research at Pringsewu High School in Lampung there have been approximately 44 types of conflicts experienced by students (student records, 2016) including fighting and brawl (Octaviyana, Firman, \& Daharnis, 2017). Other research also revealed that in Public High School 13 Bandung there had also been conflicts between departments, namely majors in Natural Sciences and Social Sciences until the conflict in the emergence of groups (gangs) in schools (Ryawan, 2017).

The pattern of adolescent life that is different from adults and children can cause social conflict (Khasanah, 2014; Siregar, 2015). In addition, adjustment and communication can also be one of the causes of conflict (Apollo \& Cahyadi, 2012, Kunniarti, Budjang, \& Imran, 2016). The problem of self-adjustment in school begins to arise when students enter the First Middle School level. They are likely to experience problems adjusting to teachers, friends, and subjects (Desneli, Firman, \& Sano, 2016). At this time, students enter adolescence where they are aged between 12-21 years (Zulkifli, 2005) and are in the transition period from children to adults (Rumini, Sri, Sundari, 2004). Self-adjustment is a dynamic process that aims to change the behavior of individuals so that a more appropriate relationship occurs between the individual and the environment. He also explained that adaptation can be understood from three perspectives, namely self-adjustment as a form of adaptation, adaptation as a form of conformity, and self-adjustment as mastery (Schneiders in Ali \& Asrori, 2006). Adjustment occurs when each individual is faced with new environmental conditions that require a response (Desmita in Nurjana, 2017). When individuals have been able to make adjustments properly then it will be able to reduce conflicts that occur (Schneiders in Desmita, 2009).

Based on the description above, the author assumes the existence of a relationship between adjustment to social conflict experienced by students, as the data that the author found in school is that there are some students experiencing social conflicts such as booing at each other, disagreement, and forcing the will which results in fights, more or less in one week there are 2-3 conflicts (counseling notes for 2018). Some of the students in class X and XI who experienced conflict turned out to also experience obstacles in self-adjustment (counseling notes in 2018), especially students of class X and transfer students who were still new to high school. Students who previously came from different junior high school backgrounds and ethnic backgrounds, many have not been able to adjust to the rules and school environment. In the end, many students decided to move even to quit school. Around 23 people resigned from school (SDI high school administrative data in 2018) because they felt uncomfortable with the rules and environment and felt uncomfortable associating with other students at school.

\section{Method}

This study uses a quantitative approach with a descriptive correlational method. The population amounted to 140 people while the sample in this study amounted to 104 students using the Stratified Random Sampling technique. The instruments used were Likert Scale questionnaire, a namely self-adjustment questionnaire with the reliability of 0.724 and social conflict questionnaire with the reliability of 0.727 . While the data analysis used is descriptive statistics and Product Moment Correlation. 


\section{Results and Discussion}

Based on the data analysis, the results of the description are as follows:

\section{Adjustment}

Table 1 Overall Adjustment of Students

\begin{tabular}{|c|c|c|c|}
\hline Category & $\begin{array}{c}\text { Percentage } \\
\text { interval }\end{array}$ & F & $\%$ \\
\hline Very High (ST) & $158-190$ & 2 & 1,92 \\
\hline Height (T) & $128-157$ & 24 & 23,08 \\
\hline Medium (S) & $98-127$ & 64 & 61,54 \\
\hline Low (R) & $68-97$ & 14 & 13,46 \\
\hline Very Low (SR) & $38-67$ & 0 & 0,00 \\
\hline \multicolumn{2}{|c|}{ Total } & 104 & 100 \\
\hline
\end{tabular}

Table 1 shows that the overall adjustment of students is in the medium category with a frequency of 64 students or $61.54 \%$. This revealed that there were still some students who needed help in improving their adjustment to be better. Which part of the students will be given guidance and counseling services related to how to improve their adjustment. For 14 students who experience very low adjustment can be provided with individual and group services.

\section{The social conflict of multiethnic students}

Table 2 social conflict experienced by students

\begin{tabular}{|c|c|c|c|}
\hline Category & $\begin{array}{l}\text { Percentage } \\
\text { interval }\end{array}$ & $\mathbf{F}$ & $\%$ \\
\hline Very High (ST) & $116-140$ & 9 & 8,65 \\
\hline Height (T) & $94-115$ & 21 & 20,19 \\
\hline Medium (S) & $72-93$ & 53 & 50,96 \\
\hline Low (R) & $50-71$ & 17 & 16,35 \\
\hline Very Low (SR) & $28-49$ & 4 & 3,85 \\
\hline \multicolumn{2}{|c|}{ Total } & 104 & 100 \\
\hline
\end{tabular}

Table 2 shows that overall social conflict experienced by students is in the moderate category with a frequency of 53 students or $50.96 \%$. This revealed that there were still many students who needed help in overcoming the conflict they were experiencing. Some of the 
students who are still experiencing social conflict will be provided guidance and counseling services related to how to reduce conflicts that occur, and for students who experience social conflict in the category of very high and high can be provided services in individual and group forms.

\section{Relationship to adjustment to the social conflict of multi-ethnic students}

Table 3 relationship of self-adjustment to the social conflict

\begin{tabular}{|c|c|c|}
\hline Variable & $\begin{array}{c}\text { Pearson } \\
\text { Correlation }\end{array}$ & Sig \\
\hline $\mathrm{X}_{1}-\mathrm{Y}$ & $-0,582$ & 0,000 \\
\hline
\end{tabular}

Table 3 shows the relationship of self-adjustment to the social conflict of multi-ethnic students where the coefficient of correlation $r$ is -0.582 with a significant level of 0.000 , this means there is a significant negative relationship between adjustment to social conflict experienced by students where the higher the level of student adjustment the lower social conflicts experienced by students as well as vice versa.

The results of the student self-adjustment data analysis are in the medium category. This means that overall there are students who are able to adjust well and there are those who have not been able to adjust well. In order for students to adjust well, supporting factors are needed (Fitria, Marsidin, \& Nirwana, 2014), including parental support so students are not easily affected by their peers' negative behavior (Kusdiyati, 2011). The results of the study revealed the ability of students to adapt, especially the ability to associate themselves with the environment in the medium category or by $59 \%$. There are still many students who cannot trust friends as a forum to express their hearts, there are also some students who experience difficulties and cannot actively involve themselves in activities at school, Fear and often ridicule causes students to lack self-confidence and are reluctant to involve in activities at school. So that in school activities that often involve themselves are only a few students who have had a high adjustment. In addition, from the results of the study there are also students who still like to harbor feelings and problems experienced. Many are reluctant to be open to friends because they feel they don't trust others and think they can solve their own problems without needing help from others. This causes students more difficulties in adjusting to the school environment. One way that can be done by counselors in schools is by providing information services related to social relations. Understanding obtained by students from information services can be used as reference material in improving students' self-adjustments (Desneli et al., 2016).

Furthermore, the results of social conflict data analysis experienced by students are in the medium category. This means that overall students still have some students who experience conflict. If seen from the indicators of social conflict, the indicator of distrust in others is in the moderate category which is equal to $66.3 \%$, the indicator of self-doubt is in the moderate category that is equal to $63.7 \%$, the indicator of competition in association is in the low category of $61 \%$, the indicators of competition in the study are in the moderate category, which is $63.5 \%$, then the loss indicator in terms of material is in the low category of $53.7 \%$, the psychological 
loss indicator is in the low category of $57.1 \%$, an indicator of misunderstanding of other people's thoughts are in the moderate category, namely $66.2 \%$ and the indicator of misunderstanding on the actions of others is in the moderate category, which is $62.2 \%$. Students who experience conflict generally lack enthusiasm for learning and participating in activities at school. Most social conflicts that occur in schools are caused by repeated scorn, so students feel intimidated (Cascardi, Brown, Iannarone, \& Cardona, 2014). This needs attention from school counselors in planning a Guidance and Counseling program to overcome this.

Then the results of the study show that self-adjustment is associated negatively significantly with social conflict experienced by multi-ethnic students. This finding is based on data analysis which shows that the correlation of both is -0.582 means that there is a significant negative relationship between adjustment to social conflict experienced by multiethnic students at SDI Silungkang High School. This shows that the better the adjustment, the lower the potential for social conflict and the smaller the ability of students to adjust, the higher the conflict that will occur. Although the strength of the relationship is in the moderate category, a good adjustment will minimize the occurrence of social conflict in SDI Silungkang High School. This is also corroborated by the results of research that show that high self-adjustment will result in good relationships with peers (Nurjana, 2017) means that if the adjustment is good then social conflict will not occur especially social conflict with peers.

\section{Conclusion}

Based on this research, it can be concluded that self-adjustment and social conflict experienced by multi-ethnic students in schools are in the moderate category, which means there are still some students who have difficulty in adjusting and experiencing social conflict in school so that they need follow-up in the form of guidance and counseling from the counselor school. In addition, there is a significant negative relationship between adjustment to social conflict experienced by multiethnic students at school. If the student's adjustment is getting better, the social conflict experienced by students decreases and vice versa.

\section{References}

Ali, M., \& Asrori. (2006). Psikologi Remaja: Perkembangan Peserta Didik. Jakarta: Bumi Aksara.

Apollo, \& Cahyadi, A. (2012). Konflik Peran Ganda Perempuan Menikah yang Bekerja Ditinjau dari Dukungan Sosial Keluarga dan Penyesuaian Diri, O(2), 254-271.

Cascardi, M., Brown, C., Iannarone, M., \& Cardona, N. (2014). The Problem with Overly Broad Definitions of Bullying; Implications for the schoolhouse, the Statehouse, and The Ivory Tower. Violoence, 13(253-276).

Desneli, Firman, \& Sano, A. (2016). Peningkatan Penyesuaian Diri Siswa melalui Layanan Orientasi. IICET, 2(2), 9-13. Retrieved from http://jurnal.iicet.org

Fitria, R., Marsidin, S., \& Nirwana, H. (2014). Hubungan Persepsi Siswa tentang Budaya Sekolah dan Motivasi Belajar dengan Penyesuaian Diri Siswa. Konselor, 3(4).

Hanurawan, F. (2012). Psikologi Sosial, Suatu Pengantar. Jakarta: Rosda.

Hasan, A. (2005). Kamus Besar Bahasa Indonesia. Jakarta: Balai Pustaka. 
Khasanah, P. (2014). Meningkatkan Kemampuan Manajemen Konflik melalui Konseling Kelompok. Psikopedagogia Jurnal Bimbingan Dan Konseling, 3(2), 67-77.

Kunniarti, D., Budjang, G., \& Imran. (2016). Faktor-faktor penyebab konflik sosial antar siswa kelas IX SMP negeri 3 sungai raya. jurnal.untan.ac.id/index.php/jpdpb/article/download/.../18307.

Kusdiyati, S. (2011). Penyesuaian Diri di Lingkungan Sekolah pada Siswa Kelas XI SMA Pasundan 2 Bandung. Jurnal Pendidikan, (Online), 2(3).

Nurjana, D. (2017). Hubungan antara Komunikasi Interpersonal dengan Penyesuaian Diri Siswa Kelas X SMA Pawyatan Daha Kediri Tahun Ajaran 2016/2017, 1(2), 0-7.

Octaviyana, I., Firman, F., \& Daharnis, daharnis. (2017). The Contribution of Social Conflict with Peers toward Self Confidence, 1(1), 10-14. https://doi.org/10.24036/007za0002

Rumini, Sri,Sundari, S. (2004). Perkembangan Anak dan Remaja. Jakarta: Rineka Cipta.

Siregar, B. (2015). Solusi dalam Menghadapi Permasalahan Remaja. Hikmah: Jurnal Ilmu Dakwah Dan Komunikasi Islam, 7(1), 100-116.

Supriyadi, B., \& Evianawati. (2015). Kematangan Sosial dan Kemampuan Mengatasi Konflik Sosial Siswa, (2013), 1-12.

Zulkifli. (2005). Manajemen Sistem Informasi. Bandung: Rosda Karya. 